\title{
Development of Ultra-Lightweight Fibre Reinforced Concrete applying expanded waste glass
}

\section{Citation for published version (APA):}

Yu, R., van Onna, D. V., Spiesz, P. R., Yu, Q. L., \& Brouwers, H. J. H. (2016). Development of Ultra-Lightweight Fibre Reinforced Concrete applying expanded waste glass. Journal of Cleaner Production, 112-p1, 690-701. https://doi.org/10.1016/j.jclepro.2015.07.082

\section{Document license:}

TAVERNE

DOI:

10.1016/j.jclepro.2015.07.082

\section{Document status and date:}

Published: 01/01/2016

\section{Document Version:}

Publisher's PDF, also known as Version of Record (includes final page, issue and volume numbers)

\section{Please check the document version of this publication:}

- A submitted manuscript is the version of the article upon submission and before peer-review. There can be important differences between the submitted version and the official published version of record. People interested in the research are advised to contact the author for the final version of the publication, or visit the $\mathrm{DOI}$ to the publisher's website.

- The final author version and the galley proof are versions of the publication after peer review.

- The final published version features the final layout of the paper including the volume, issue and page numbers.

Link to publication

\section{General rights}

Copyright and moral rights for the publications made accessible in the public portal are retained by the authors and/or other copyright owners and it is a condition of accessing publications that users recognise and abide by the legal requirements associated with these rights.

- Users may download and print one copy of any publication from the public portal for the purpose of private study or research.

- You may not further distribute the material or use it for any profit-making activity or commercial gain

- You may freely distribute the URL identifying the publication in the public portal.

If the publication is distributed under the terms of Article 25fa of the Dutch Copyright Act, indicated by the "Taverne" license above, please follow below link for the End User Agreement:

www.tue.nl/taverne

Take down policy

If you believe that this document breaches copyright please contact us at:

openaccess@tue.nl

providing details and we will investigate your claim. 


\title{
Development of Ultra-Lightweight Fibre Reinforced Concrete applying expanded waste glass
}

\author{
R. Yu ${ }^{\text {a, }}$, D.V. van Onna ${ }^{\text {a }}$, P. Spiesz ${ }^{\text {a, b }}$, Q.L. Yu ${ }^{\text {a }}$, H.J.H. Brouwers ${ }^{a}$ \\ a Department of the Built Environment, Eindhoven University of Technology, The Netherlands \\ ${ }^{\mathrm{b}}$ ENCI HeidelbergCement Benelux, The Netherlands
}

\section{A R T I C L E I N F O}

\section{Article history:}

Received 18 December 2014

Received in revised form

16 June 2015

Accepted 14 July 2015

Available online 21 July 2015

\section{Keywords:}

Ultra-Lightweight Fibre Reinforced Concrete

(ULFRC)

Expanded waste glass

Polypropylene fibres

Density

Thermal conductivity

Mechanical properties

\begin{abstract}
A B S T R A C T
This paper presents the development of Ultra-Lightweight Fibre Reinforced Concrete (ULFRC) applying expanded waste glass in form of lightweight aggregates. The modified Andreasen \& Andersen particle packing model and an optimal amount of polypropylene fibres are utilized in the design and production of ULFRC. The density, mechanical properties and thermal conductivity of the developed ULFRC are measured and analyzed. The ULFRC with a dry density of $750 \mathrm{~kg} / \mathrm{m}^{3}$ is produced. It is found that hybridization and an optimized amount of polypropylene fibres are beneficial for improving the mechanical properties of ULFRC. Moreover, compared to the other lightweight concretes with the same density, the ULFRC developed in this study has improved mechanical properties and lower thermal conductivity, therefore it can be utilized as a new material for the production of floating structures, insulating elements or even for load bearing applications. As sustainable development is currently a crucial global issue and various industries are striving to save the energy and lower the environmental impact, the developed ULFRC has a good prospect in the near future.
\end{abstract}

() 2015 Elsevier Ltd. All rights reserved.

\section{Introduction}

Concrete is one of the most widely used building materials throughout the world. Nevertheless, due to the fact that the sustainable development is currently a crucial global issue and various industries are striving to save the energy and lower the environmental impact, also concrete is more frequently required to possess more advanced characteristics, such as low cost, low density, low thermal conductivity, good mechanical properties and ecofriendliness (Yang et al., 2013, 2014; Yu and Shui, 2013; Yu et al., 2014b; Bravo et al., 2015). Lightweight concrete (LWC) is one type of concrete having a dry density of not less than $800 \mathrm{~kg} / \mathrm{m}^{3}$ and not more than $2000 \mathrm{~kg} / \mathrm{m}^{3}$ (EN 206-1, 2001), which can be traced back to around 3000 years ago (Chandra and Berntsson, 2003). Some investigations have demonstrated that the thermal insulation and fire resistance capacities of LWC are much better than for normal weight concrete (NWC), and LWC is suitable to be applied as both structural and non-structural material (Pelisser et al., 2012; Shafigh et al., 2014). In general, the methods of LWC production can be

\footnotetext{
* Corresponding author. Tel.: +31 (0) 40247 5469; fax: +31 (0) 402438595 .

E-mail address: r.yu@tue.nl (R. Yu).
}

mainly summarized as follows (Chandra and Berntsson, 2003): 1) Adding lightweight aggregates (LWA) into concrete mixtures, replacing partially or completely conventional normal density aggregates; 2) Adding a foaming or air-entraining agent into the mixture in order to introduce a certain volume of air voids into the matrix of concrete; 3) Gap grading (poor packing density of the solid ingredients) of the mixture (e.g. applying no fine aggregates in the concrete mixture). Nevertheless, due to the use of various LWAs, foaming agents and applied production methods, it is possible to obtain a large variety of the properties (density, mechanical properties, thermal properties and durability) of LWCs (Chandra and Berntsson, 2003; Topçu et al., 2010; Neville, 2011; Schauerte and Trettin, 2012). Additionally, experimental investigations (Neville, 2011) showed that both thermal conductivity and mechanical properties of LWC are strongly linked with its density. Neville (2011) reported that there is a linear correlation between the thermal conductivity and the density of LWC produced with different types of LWAs, such as pumice, vermiculite, cinders, expanded shale and expanded slag. Chandra and Berntsson (2003) presented a relationship between the compressive strength and density of LWC applying expanded clay as LWA, for which the compressive strength of LWC increases from 7 to $16 \mathrm{MPa}$ as its density increases from 1000 to $1500 \mathrm{~kg} / \mathrm{m}^{3}$. Therefore, it is difficult 
to produce a specific LWC that simultaneously has a low density, good mechanical properties and a low thermal conductivity.

As commonly known, the use of glass products have increased tremendously in recent decades, which has resulted in large amounts of waste glass (Rashad, 2014). For example, it was estimated that the total amount of waste glass generated in the EU-27 in 2007 was $25.8 \mathrm{Mt}$. In Hong Kong, approximately 373 tons of waste glass is generated daily in 2010. With the development of recycling technology and garbage classification, some waste glass can be recycled for the production of new glass. However, still some waste glass is unsuitable to be reused. For example, in 2010, approximately 425,000 tons of waste glass was produced in Portugal and only 192,000 tons of them were recycled. Nowadays, the disposal of this unrecyclable waste glass is an urgent environmental topic all over the world, since the non-biodegradable nature of glass leads to that a large volume of landfills spaces needed and accompanying environmental pollutions of air, water on soil can be an issue (Castro and Brito, 2013). The best solution to minimize the above mentioned problems with unrecyclable waste glass is to appropriately reuse them in other industries. As can be found in the available literature (Ling and Poon, 2012; Castro and Brito, 2013; Ling and Poon, 2014), the construction industry is one of the most attractive ways to solve the environmental impact of the unrecyclable waste glass. After cleaning and crushing, the waste glass can be used as aggregates in the production of concrete. Additionally, when the recycled glass is fineground, mixed and formed, a type of expanded glass granulate can be produced via a special production method, with a smooth surface and very low density $\left(300-800 \mathrm{~kg} / \mathrm{m}^{3}\right)$. Based on some previous research by Yu et al. (2013, 2014a, 2015a), it is demonstrated that this expanded glass granulate can be utilized to produce an ultra-lightweight concrete (ULWC) with both low density and low thermal conductivity. As the sustainable development is currently a pressing global issue, the developed ULWC is very suitable to be used in practice as a new building material, to be applied as both load bearing element and thermal insulator. Nevertheless, due to the fact that the generated expanded glass granulate has a relatively low crushing resistance, the mechanical properties of ULWC still need to be further addressed, in order to widen its application potential.

According to the available literature, it can be noticed that the LWC is normally weaker than normal density concrete (NDC), which to some extent restricts its wider application (Kidalova et al., 2012; Choi et al., 2014). To overcome this disadvantage, adding fibres into LWC can be a promising solution. There are mainly three types of fibres utilized in concrete production: metallic fibres (most commonly used), polymeric fibres and natural fibres. In general, fibres can bridge cracks and retard their propagation, which directly result in an increase of the strength (especially the flexural strength) of concrete (Grünewald, 2004; Markovic, 2006; Guo et al., 2014). Experimental results show that the addition of steel fibres can significantly improve the mechanical properties and toughness of concrete. However, due to the fact that the density and thermal conductivity of steel fibre are around $7.8 \mathrm{~kg} / \mathrm{m}^{3}$ and $16 \mathrm{~W} /(\mathrm{m} \mathrm{K})$, respectively, the addition of steel fibres may obviously increase the density and thermal conductivity of LWC. Hence, to further improve the mechanical properties of LWC without increasing its density and thermal conductivity, polymeric fibres potentially are a good choice. Investigations regarding polymeric fibres reinforced LWC have been reported by Kayali et al. (2003), Mazaheripour et al. (2011) and Libre et al. (2011). Nevertheless, research focusing on the development of polymeric fibres reinforced ultra-lightweight concrete (ULWC) with low density, low thermal conductivity and good mechanical properties has never been published to the authors' knowledge.
In the view of the above, the objective of this study is to develop an Ultra-Lightweight Fibre Reinforced Concrete (ULFRC) with low density, low thermal conductivity and good mechanical properties. To achieve a low density and low thermal conductivity, one type of LWA (sourced from waste glass) is utilized in the production of ULFRC. Moreover, to achieve good mechanical properties, the modified Andreasen \& Andersen particle packing model is utilized to design a densely compacted concrete matrix and polypropylene fibres are added into the concrete matrix to further improve its mechanical properties.

\section{Materials and methods}

\subsection{Materials}

The cement used in this study is Ordinary Portland Cement (OPC) CEM I 52.5 R, provided by ENCI B.V., HeidelbergCement (the Netherlands). The chemical composition of the used cement is shown in Table 1. A polycarboxylic ether based superplasticizer (SP) is used to adjust the workability of concrete. One type of expanded waste glass is utilized as lightweight aggregates (LWA) to produce concrete. The LWA are delivered in the following size fractions: $0.1-0.3 \mathrm{~mm}, 0.25-0.5 \mathrm{~mm}, 0.5-1.0 \mathrm{~mm}, 1.0-2.0 \mathrm{~mm}, 2.0-4.0 \mathrm{~mm}$ and $4.0-8.0 \mathrm{~mm}$ (as shown in Fig. 1). The physical properties and chemical composition of the LWA are presented in Tables 1 and 2. Fig. 2 presents the SEM images of the utilized LWA. It can be noticed that the used LWA have a relatively smooth surface and are composed of a closed external shell and a number of internal air pores encapsulated within the shell. This should be the reason that these LWA have lower water absorption (less than $2 \%$ after soaking in water for $1 \mathrm{~h}$ ) compared to the other market available LWAs (Yu et al., 2015a). Therefore, in this study, the expanded waste glass (LWA) is used in concrete directly, without pre-soaking in water beforehand or adding extra water. Additionally, two types of polypropylene fibres are applied, as shown in Fig. 3: 1) relatively stiff and long polypropylene fibre (LPF), length $=45 \mathrm{~mm}$, diameter $=0.5 \mathrm{~mm} ; 2$ ) relatively soft and short polypropylene fibre $(\mathrm{SPF})$, length $=18 \mathrm{~mm}$, diameter $=22 \mu \mathrm{m}$. The specific density, tensile strength and thermal conductivity of the utilized polypropylene fibres are about $910 \mathrm{~kg} / \mathrm{m}^{3}, 400 \mathrm{MPa}$ and $0.16 \mathrm{~W} /(\mathrm{m} \mathrm{K})$, respectively.

\subsection{Experimental methodology}

\subsubsection{Mix design of ULFRC}

An optimum packing of the granular ingredients of concrete has been proved to be the key for stronger and more durable concretes (Hüsken and Brouwers, 2008; Hunger, 2010). For the design of mortars and concretes, several mix design tools are in use. De

Table 1

Chemical composition of the used cement and LWA

\begin{tabular}{lll}
\hline Substance & Cement (mass \%) & LWA (mass \%) \\
\hline $\mathrm{CaO}$ & 64.60 & $8 \pm 2$ \\
$\mathrm{SiO}_{2}$ & 20.08 & $71 \pm 2$ \\
$\mathrm{Al}_{2} \mathrm{O}_{3}$ & 4.98 & $2 \pm 0.3$ \\
$\mathrm{Fe}_{2} \mathrm{O}_{3}$ & 3.24 & $0.5 \pm 0.2$ \\
$\mathrm{~K}_{2} \mathrm{O}$ & 0.53 & $1 \pm 0.2$ \\
$\mathrm{Na}_{2} \mathrm{O}$ & 0.27 & $13 \pm 1$ \\
$\mathrm{SO}_{3}$ & 3.13 & - \\
$\mathrm{MgO}^{\mathrm{TiO}}$ & 1.98 & $2 \pm 1$ \\
$\mathrm{Mn}_{3} \mathrm{O}_{4}$ & 0.30 & - \\
$\mathrm{P}_{2} \mathrm{O}_{5}$ & 0.10 & - \\
$\mathrm{Cl}^{-}$ & 0.74 & - \\
\hline
\end{tabular}

a Provided by the supplier of LWA. 

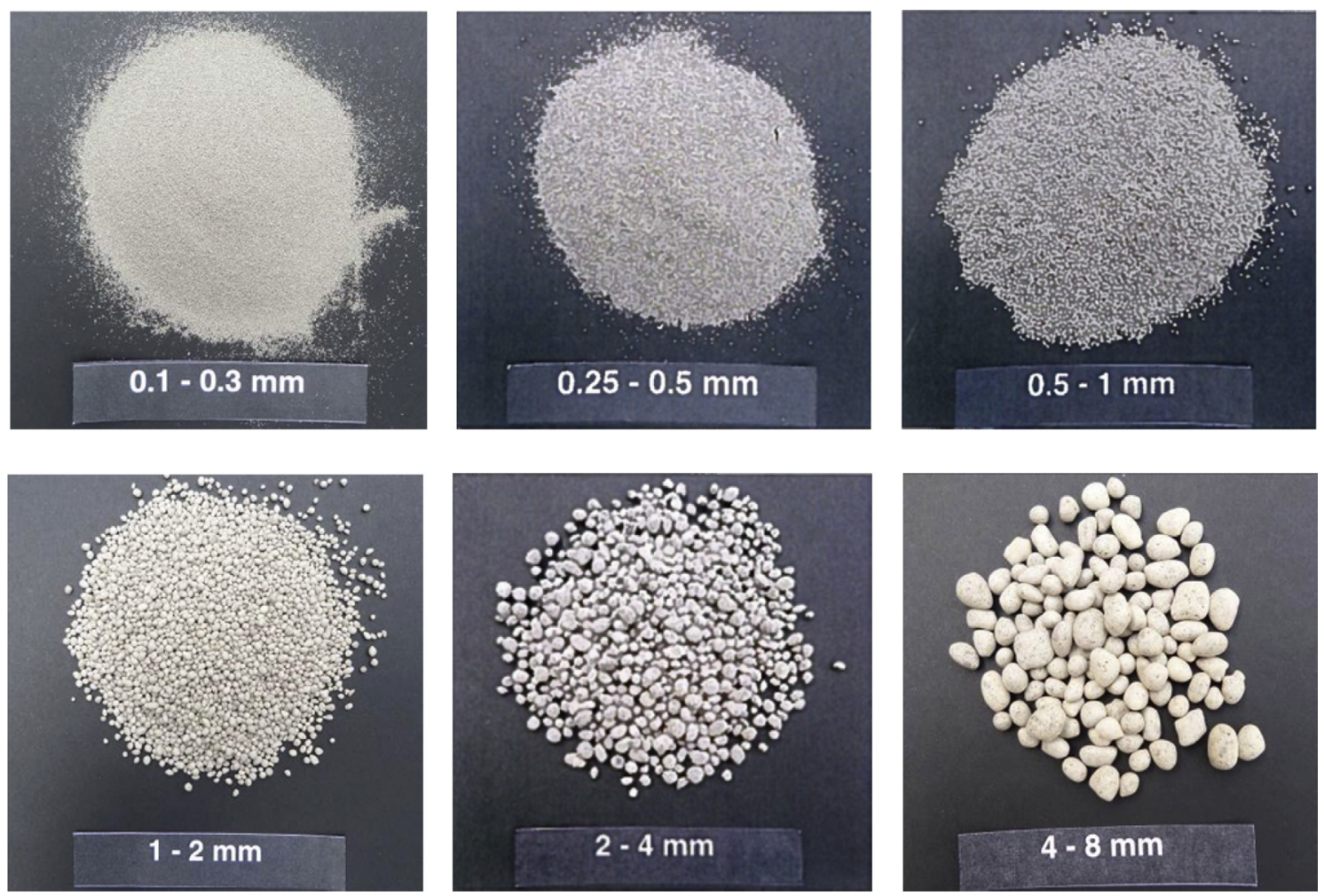

Fig. 1. Utilized lightweight aggregates (LWA) (expanded waste glass).

Table 2

Physical properties of the used light-weight aggregates (LWA).

\begin{tabular}{llllll}
\hline $\begin{array}{l}\text { Materials size } \\
\text { range }(\mathrm{mm})\end{array}$ & $\begin{array}{l}\text { Bulk } \\
\text { density } \\
\left(\mathrm{kg} / \mathrm{m}^{3}\right)\end{array}$ & $\begin{array}{l}\text { Specific } \\
\text { density } \\
\left(\mathrm{kg} / \mathrm{m}^{3}\right)\end{array}$ & $\begin{array}{l}\text { Crushing } \\
\text { resistance } \\
\left(\mathrm{N} / \mathrm{mm}^{2}\right)\end{array}$ & $\begin{array}{l}\text { 1 h water } \\
\text { absorption } \\
(\text { wt.\%) }\end{array}$ & $\begin{array}{l}\text { 24 h water } \\
\text { absorption } \\
(\text { wt.\%) }\end{array}$ \\
\hline LWA 0.1-0.3 & 450 & 810 & $>3.5$ & 1.06 & 2.81 \\
LWA 0.25-0.5 & 300 & 540 & $>2.9$ & 0.88 & 3.90 \\
LWA 0.5-1.0 & 350 & 450 & $>2.6$ & 1.59 & 8.50 \\
LWA 1.0-2.0 & 220 & 350 & $>2.4$ & 1.71 & 7.63 \\
LWA 2.0-4.0 & 190 & 310 & $>2.2$ & 0.55 & 7.80 \\
LWA 4.0-8.0 & 170 & 300 & $>2.0$ & 1.30 & 9.11 \\
\hline
\end{tabular}

(Part of the data is obtained from (Yu et al., 2015a)).

Larrard and Sedran $(1994,2002)$ postulated different approaches to design concrete: the Linear Packing Density Model (LPDM), Solid Suspension Model (SSM) and Compressive Packing Model (CPM). Fennis et al. (2009) developed a concrete mix design method based on the concepts of De Larrard and Sedran. To consider the influence of fine particles on the particle packing skeleton, Funk and Dinger (1994) proposed a modified model based on the Andreasen and Andersen equation In this study, the so-called modified Andreasen and Andersen particle packing model is utilized to design the concrete mixture, which is shown as follows (Andreasen and Andersen, 1930; Funk and Dinger, 1994; Brouwers and Radix, 2005):

$P(D)=\frac{D^{q}-D_{\min }^{q}}{D_{\max }^{q}-D_{\min }^{q}}$

where $D$ is the particle size $(\mu \mathrm{m}), P(D)$ is the fraction of the total solids smaller than size $D, D_{\max }$ is the maximum particle size $(\mu \mathrm{m})$, $D_{\min }$ is the minimum particle size $(\mu \mathrm{m})$ and $q$ is the distribution modulus.
The modified Andreasen and Andersen particle packing model has already been successfully employed in optimization algorithms for the design of different types of concrete (Hüsken and Brouwers, 2008; Yu et al., 2014c, 2014d, 2014e, 2015b; Quercia et al., 2014). Different types of concrete can be designed using Eq. (1) by applying different values of the distribution modulus q, as it determines the proportion between the fine and coarse particles in the mixture. In this study, based on the recommendations given by Hunger (2010) and Yu et al. (2015a), the value of q is fixed at 0.35. The modified Andreasen and Andersen model (Eq. (1)) acts as a target function for the optimization of the composition of mixture of granular materials. The proportions of each individual material in the mix are adjusted until an optimum fit between the composed mix and the target curve is reached, using an optimization algorithm based on the Least Squares Method (LSM), as presented as follows:

$$
R S S=\frac{\sum_{i=1}^{n}\left(P_{\text {mix }}\left(D_{i}^{i+1}\right)-P_{\operatorname{tar}}\left(D_{i}^{i+1}\right)\right)^{2}}{n}
$$

where $P_{\text {mix }}$ is the composed mix, and the $P_{\text {tar }}$ is the target grading calculated from Eq. (1).

As commonly accepted, the quality of the curve fit is assessed by the coefficient of determination $\left(R^{2}\right)$, since it gives a value for the correlation between the grading of the target curve and the composed mix. Therefore, the coefficient of determination $\left(R^{2}\right)$ is utilized in this study to obtain the optimized mixture given by:

$$
R^{2}=1-\frac{\sum_{i=1}^{n}\left(P_{\text {mix }}\left(D_{i}^{i+1}\right)-P_{\text {tar }}\left(D_{i}^{i+1}\right)\right)^{2}}{\sum_{i=1}^{n}\left(P_{\text {mix }}\left(D_{i}^{i+1}\right)-\overline{P_{\text {mix }}}\right)^{2}}
$$




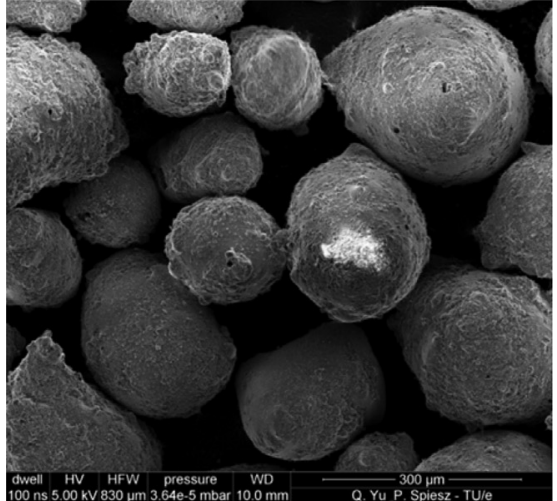

a) LWA 0.1-0.3

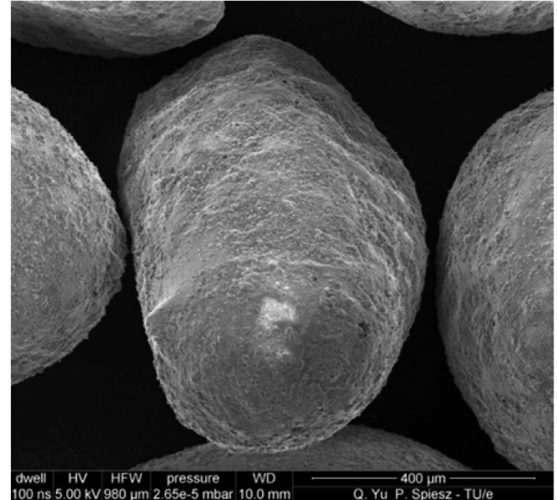

c) LWA $0.5-1.0$

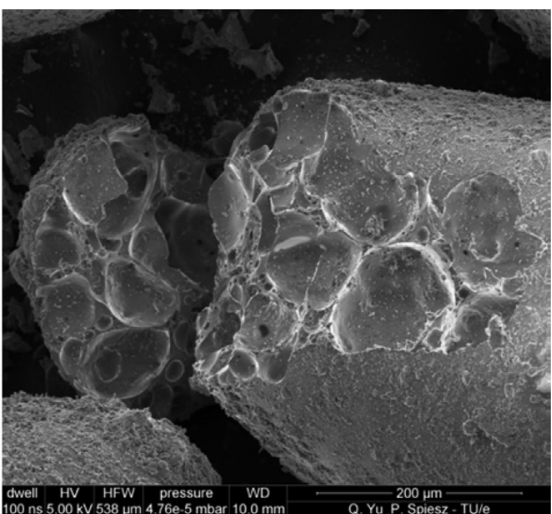

b) LWA $0.25-0.5$

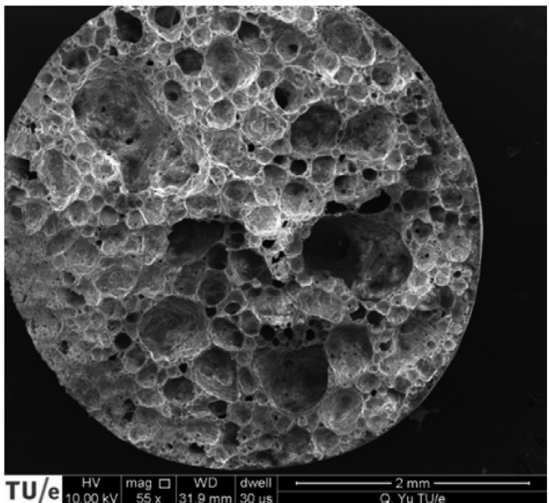

d) LWA 2.0-4.0

Fig. 2. SEM pictures of the utilized light weight aggregates (LWA).

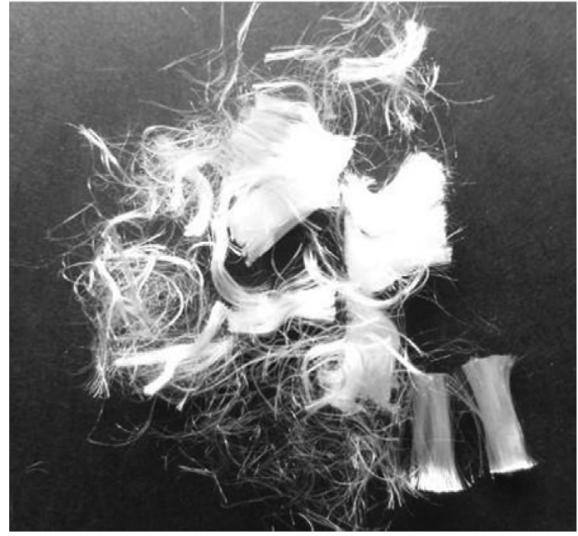

a)

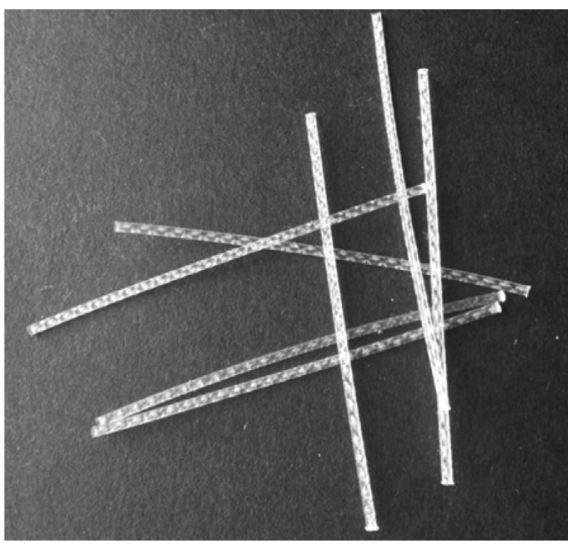

b)

Fig. 3. Utilized polypropylene fibres: a) Length $=18 \mathrm{~mm}$, diameter $=22 \mu \mathrm{m}$, b) Length $=45 \mathrm{~mm}$, diameter $=0.5 \mathrm{~mm}$.

Where $\overline{P_{\text {mix }}}=\frac{1}{n} \sum_{i=1}^{n} P_{\text {mix }}\left(D_{i}^{i+1}\right)$, which represents the mean of the entire distribution.

Additionally, the water and SP amounts are very important to produce the ULFRC. As shown in Table 2, the applied LWAs have a very low particle density, ranging from 300 to $810 \mathrm{~kg} / \mathrm{m}^{3}$, which indicates the possibility of segregation of cement paste and the LWA in fresh concrete state, if the amount of water and SP amount are not properly selected. However, due to the fact that the polypropylene fibres can reduce the workability of concrete, the SP and water amount should be appropriately adjusted compared to the ULWC mixtures without fibres. Hence, to simultaneously avoid the appearance of segregation and mostly improve the workability of ULFRC, a water/cement ratio of 0.4 and added SP amount of $0.5 \%$ by the mass of cement are determined in this study. The compositions of the ULFRC mixtures developed based on the optimized particle packing model are listed in Table 3. The resulting integral 
grading curve of the composite mixes is shown in Fig. 4 (the calculated $\mathrm{R}^{2}$ is about 0.999 ). In total, 1 reference mixture (without fibres) and 9 ULFRC mixtures are designed in this study. According to the recommendation of polypropylene fibre amount from the fibre supplier, ULFRC mixtures No. 1-3 (with only LPF) are designed. Then, to evaluate the hybrid polypropylene fibres influence on the properties of ULFRC, the LPF and SPF are simultaneously added into the concrete matrix, while the total fibre amount is fixed at $0.2 \%$ (vol.). Finally, to further analyze the influence of the higher fibre content on the characteristics of ULFRC, the LPF is added into the concrete matrix at $0.6 \%, 0.9 \%$ and $1.2 \%$ (vol.), respectively.

\subsubsection{Mixing procedures and fresh behaviour}

In this study, the cement and LWA are firstly mixed in the mixer in dry state for about $1 \mathrm{~min}$. Then, around $75 \%$ of water is added and mixed with the cement and LWA for about $2 \mathrm{~min}$. Afterwards, the SP and remaining water are added into the mixer and mixed for additional two minutes. Subsequently, the polypropylene fibres are slowly added into the mixer until the end of the mixing procedures. The mixing process takes about $7 \mathrm{~min}$ in total. The mixing is always executed under laboratory conditions with dried and tempered aggregates and powder materials. The room temperature during the mixing and testing is constant, around $21{ }^{\circ} \mathrm{C}$. Following the European standard BS EN 12350-5 (2009), the slump and flow of the fresh ULFRC are about $135 \mathrm{~mm}$ and $348 \mathrm{~mm}$ (corresponding to $\mathrm{S}_{3}$ and $\mathrm{F}_{2}$ classes, according to EN 206-1), respectively.

\subsubsection{Hardened density}

After mixing, the fresh ULFRC is cast into molds of with different sizes: $100 \mathrm{~mm} \times 100 \mathrm{~mm} \times 100 \mathrm{~mm}, 150 \mathrm{~mm} \times 150 \mathrm{~mm} \times 150 \mathrm{~mm}$ and $100 \mathrm{~mm} \times 100 \mathrm{~mm} \times 500 \mathrm{~mm}$, and compacted on a vibration table for about $1 \mathrm{~min}$. Subsequently, the cubes and beams are stripped from the moulds after $24 \mathrm{~h}$ from casting, and stored in a climate chamber with a relative humidity of over $95 \%$, at room temperature (around $20{ }^{\circ} \mathrm{C}$ ), following EN 12390-2 (2000). After curing for 28 days, the small cubes $(100 \mathrm{~mm} \times 100 \mathrm{~mm} \times 100 \mathrm{~mm}$ ) are utilized to determine the density of ULFRC, following EN 12390-7 (2009). In this study, two types of densities are measured: apparent wet and dry density. For the wet density, the sample is measured directly with dry surface after curing for 28 days. Prior to the drydensity measurement, the samples are dried in a ventilated oven at $105{ }^{\circ} \mathrm{C}$ until a constant mass is reached.

\subsubsection{Mechanical properties}

The cubes $(150 \mathrm{~mm} \times 150 \mathrm{~mm} \times 150 \mathrm{~mm}$ ) are used to determine the compressive strength of ULFRC after 28 days, following EN 12390-3 (2009), while the beams (100 $\mathrm{mm} \times 100 \mathrm{~mm} \times 500 \mathrm{~mm})$ are subjected to the 4-point bending test, as described in EN 12390-5 (2009). For the 4-point bending test, the span between the two supported points at the bottom is $400 \mathrm{~mm}$. To obtain the flexural load over the middle displacement curve, a Linear Variable Differential Transformer (LVDT) mounted on the surface of the tested samples is utilized to record the displacement. During the test, the set-up is running in a displacement control mode, which is set at $0.1 \mathrm{~mm} / \mathrm{min}$. Before the test, the calibration of the used LVDT is done.

\subsubsection{Thermal conductivity}

Similar to the density measurements, for the thermal conductivity test, the samples $(100 \mathrm{~mm} \times 100 \mathrm{~mm} \times 100 \mathrm{~mm})$ are dried in a ventilated oven at $105{ }^{\circ} \mathrm{C}$ until a constant mass following EN 12390-7 (2009). Afterwards, the samples are cooled down to the room temperature. Finally, the thermal conductivity is measured by a heat transfer analyzer (ISOMET model, 2014). This analyzer applies a dynamic measurement method to determine simultaneously the volumetric heat capacity $\left(\mathrm{J} /\left(\mathrm{m}^{3} \cdot \mathrm{K}\right)\right)$ and the thermal conductivity $(\mathrm{W} /(\mathrm{m} \mathrm{K}))$ of materials with a measurement time of about $15 \mathrm{~min}$. The measurement is based on the analysis of the temperature response of the tested sample to heat flow impulses, while the heat flow is excited by the electrical heating of a resistor heater inserted into the probe, which is in direct contact with the tested samples.

\section{Results and discussion}

\subsection{Densities}

The apparent wet and dry densities of ULFRC are illustrated in Fig. 5. It is important to notice that the dry densities of all the designed ULFRC are less than $800 \mathrm{~kg} / \mathrm{m}^{3}$, which is out of the range of LWC defined by the standard - EN 206-1 (2001). Therefore, it can be stated that the concrete developed in this study is an ultralightweight concrete. Due to the very low density, the developed ULFRC has an ability to float on the water, which could be significantly beneficial for its wider application in practice. For instance, the developed ULFRC can be applied in the production of marine and floating constructions, since the available lands are prominently decreasing and there is a strong demand for developing new building types. Moreover, due to the fact that low density normally means relatively low thermal conductivity, the developed ULFRC may also be utilized as thermal insulating building material.

From Fig. 5, it can also noticed that the dry densities of the mixtures No. 1-7 fluctuate around $750 \mathrm{~kg} / \mathrm{m}^{3}$, while the densities of the mixtures No. 8 and No. 9 are relatively smaller than those of other mixtures. Particularly, for the concrete mixture No. 9, whose dry and wet densities are around 720 and $790 \mathrm{~kg} / \mathrm{m}^{3}$, respectively. This should be attributed to the effect of large amount of fibres on the internal structure of ULFRC. As shown in Table 3, around $1.2 \%$

Table 3

Recipes of the developed ULFRC.

\begin{tabular}{|c|c|c|c|c|c|c|c|c|c|c|c|}
\hline No. & $\mathrm{C} \mathrm{kg} / \mathrm{m}^{3}$ & LWA-1 $\mathrm{kg} / \mathrm{m}^{3}$ & LWA-2 $\mathrm{kg} / \mathrm{m}^{3}$ & LWA-3 kg/m $\mathrm{m}^{3}$ & LWA-4 kg/m $/ \mathrm{m}^{3}$ & LWA-5 $\mathrm{kg} / \mathrm{m}^{3}$ & LWA-6 kg/m $\mathrm{m}^{3}$ & $\mathrm{~W} \mathrm{~kg} / \mathrm{m}^{3}$ & $\mathrm{SP} \mathrm{kg} / \mathrm{m}^{3}$ & LPF vol.\% & SPF vol.\% \\
\hline Ref. & 350.0 & 92.2 & 16.1 & 35.4 & 31.7 & 54.6 & 68.9 & 140 & 1.75 & 0 & 0 \\
\hline 1 & 350.0 & 92.2 & 16.1 & 35.4 & 31.7 & 54.6 & 68.9 & 140 & 1.75 & 0.1 & 0 \\
\hline 2 & 350.0 & 92.2 & 16.1 & 35.4 & 31.7 & 54.6 & 68.9 & 140 & 1.75 & 0.2 & 0 \\
\hline 3 & 350.0 & 92.2 & 16.1 & 35.4 & 31.7 & 54.6 & 68.9 & 140 & 1.75 & 0.3 & 0 \\
\hline 4 & 350.0 & 92.2 & 16.1 & 35.4 & 31.7 & 54.6 & 68.9 & 140 & 1.75 & 0.15 & 0.05 \\
\hline 5 & 350.0 & 92.2 & 16.1 & 35.4 & 31.7 & 54.6 & 68.9 & 140 & 1.75 & 0.1 & 0.1 \\
\hline 6 & 350.0 & 92.2 & 16.1 & 35.4 & 31.7 & 54.6 & 68.9 & 140 & 1.75 & 0.05 & 0.15 \\
\hline 7 & 350.0 & 92.2 & 16.1 & 35.4 & 31.7 & 54.6 & 68.9 & 140 & 1.75 & 0.6 & 0 \\
\hline 8 & 350.0 & 92.2 & 16.1 & 35.4 & 31.7 & 54.6 & 68.9 & 140 & 1.75 & 0.9 & 0 \\
\hline 9 & 350.0 & 92.2 & 16.1 & 35.4 & 31.7 & 54.6 & 68.9 & 140 & 1.75 & 1.2 & 0 \\
\hline
\end{tabular}

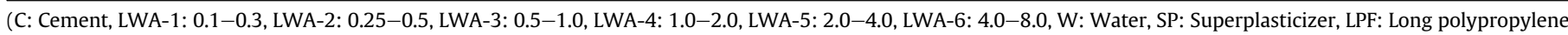
fibre, SPF: Short polypropylene fibre, Ref.: reference sample). 


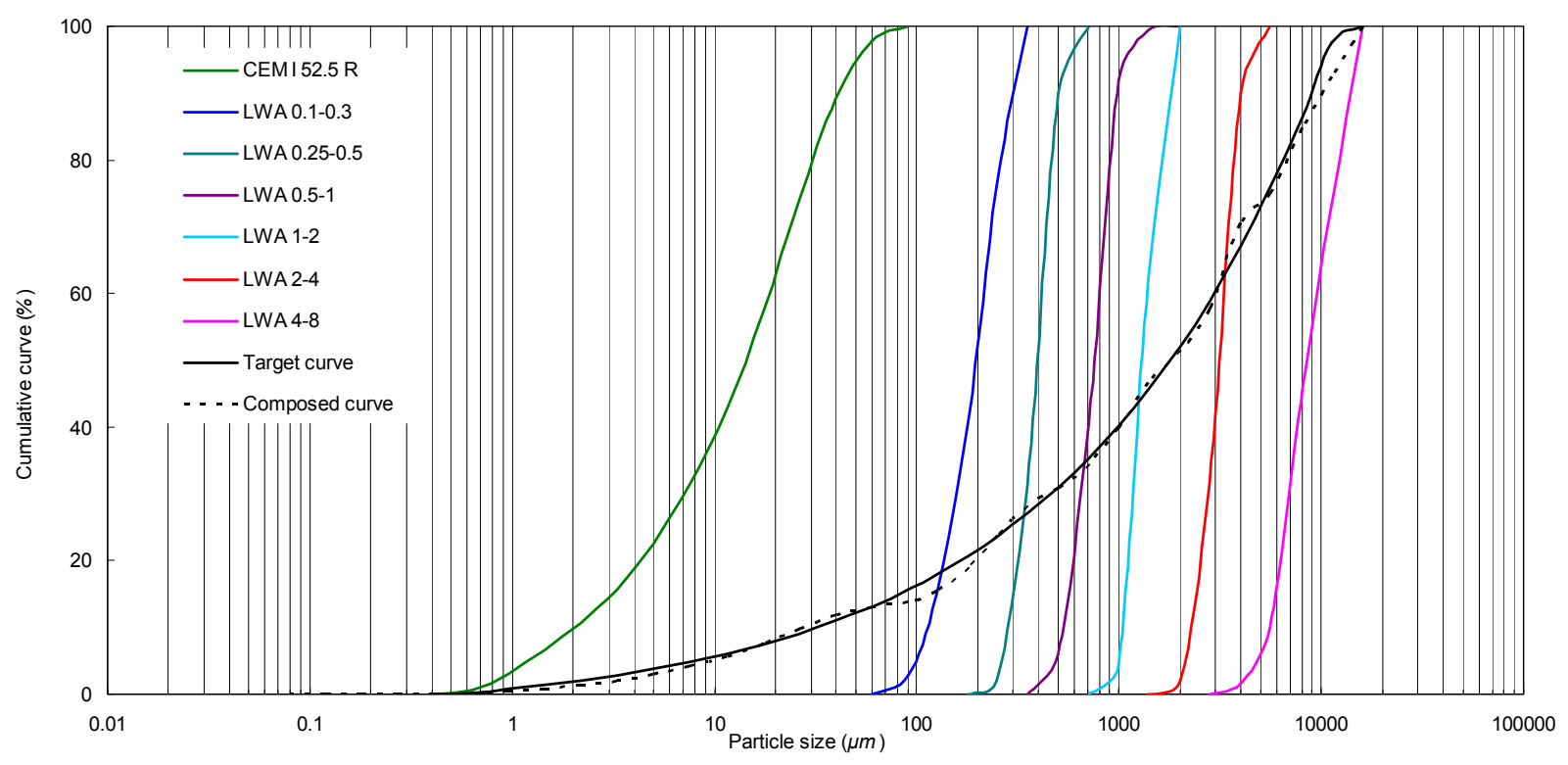

Fig. 4. PSDs of the ingredients, the target curve and the resulting integral grading curve of the composed mixture.

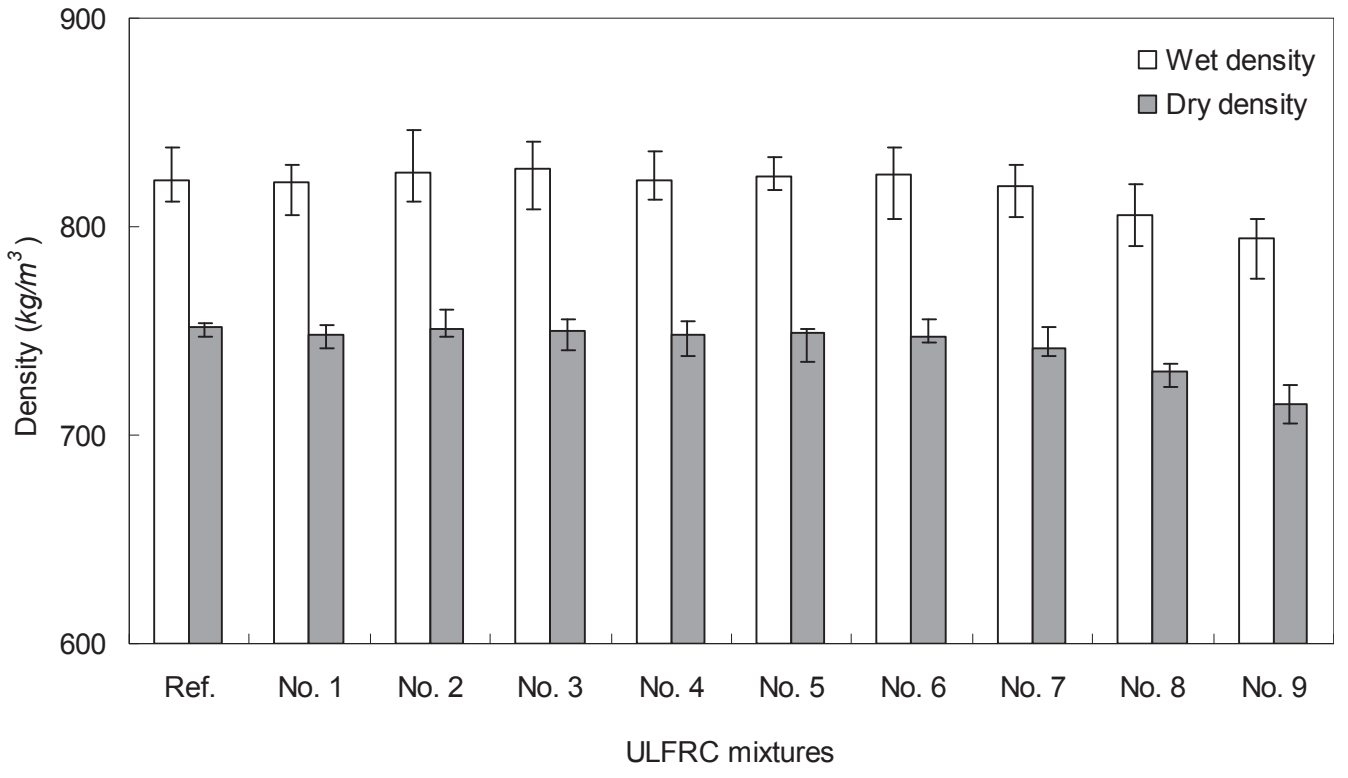

Fig. 5. Densities of the designed ULFRC.

LPF (vol.) is added in the mixture No. 9. Due to the fact that the utilized LPF is relatively stiff, it can push the surrounding particles (mainly low density LWA) and alter the structure of the granular skeleton. Therefore, when the additional fibre content is relatively high, a number of air voids will be entrapped into the ULFRC, which cause that the concrete is more porous (as shown in Fig. 6) and its density is decreased. The porous structure of ULFRC (as shown in Fig. 6) may cause a negative influence on its mechanical properties, which is elaborated in the following part.

\subsection{Mechanical properties}

\subsubsection{Compressive behaviour}

Fig. 7 reveals the compressive strength of the developed ULFRC at 28 days. It is clear that the addition of polypropylene fibres improves the compressive strength of ULWC, which is similar to the effect of steel fibres on the mechanical properties of normal density concrete. Moreover, the results for mixtures No. 1-3 (with recommended fibre amount by the supplier, $0.1 \%, 0.2 \%$ and $0.3 \%$ vol.) show that with an increase of the LPF amount, the compressive strength of ULFRC at 28 days gradually increases from 11.8 to 13.1 MPa. These results are in accordance with the phenomena observed by other researchers (Kayali et al., 2003; Mazaheripour et al., 2011; Libre et al., 2011). The polypropylene fibers could restrict the crack formation and development and thus lead to an increase of the compressive strength. Moreover, in this study, it can be noticed that the utilized long polypropylene fibre has a relatively rough surface (as shown in Fig. 3), which can strengthen the adhesion between the concrete matrix and fibres, and is beneficial for improving the compressive strength of ULFRC. 


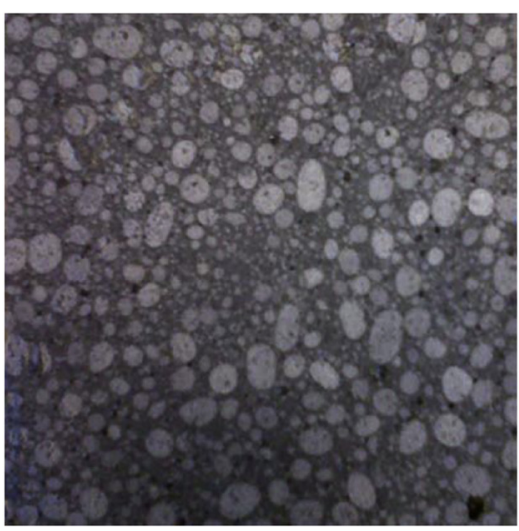

(a)

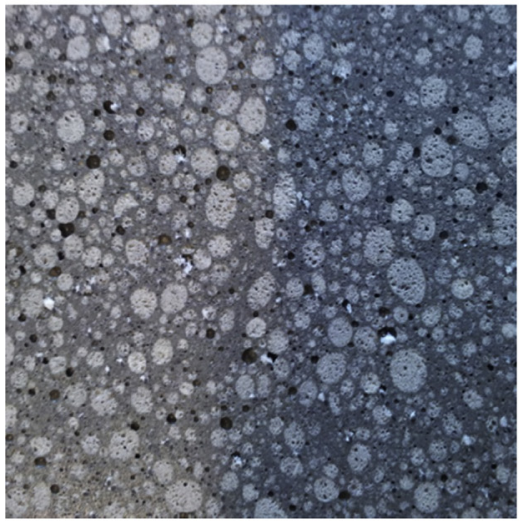

(c)

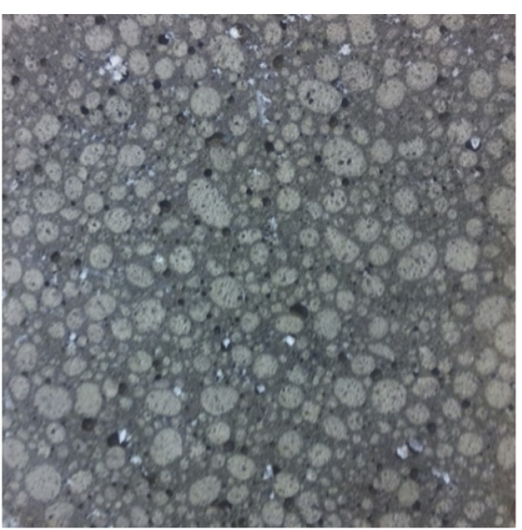

(b)

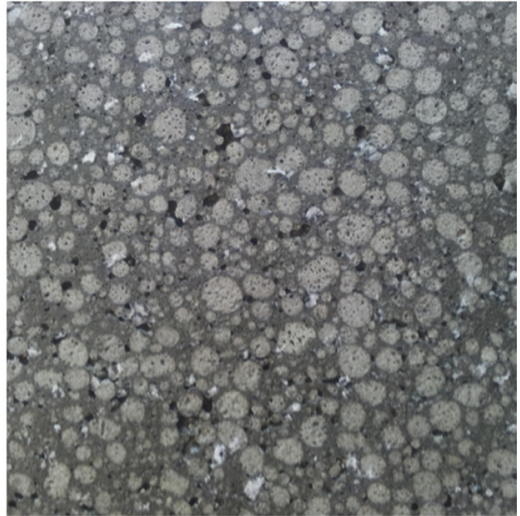

(d)

Fig. 6. Lightweight aggregates distribution in ULFRC cross-section, (a): without fibres (reference), (b): with $0.6 \%$ LPF, (c): with $0.9 \%$ LPF, (d): with $1.2 \%$ LPF.

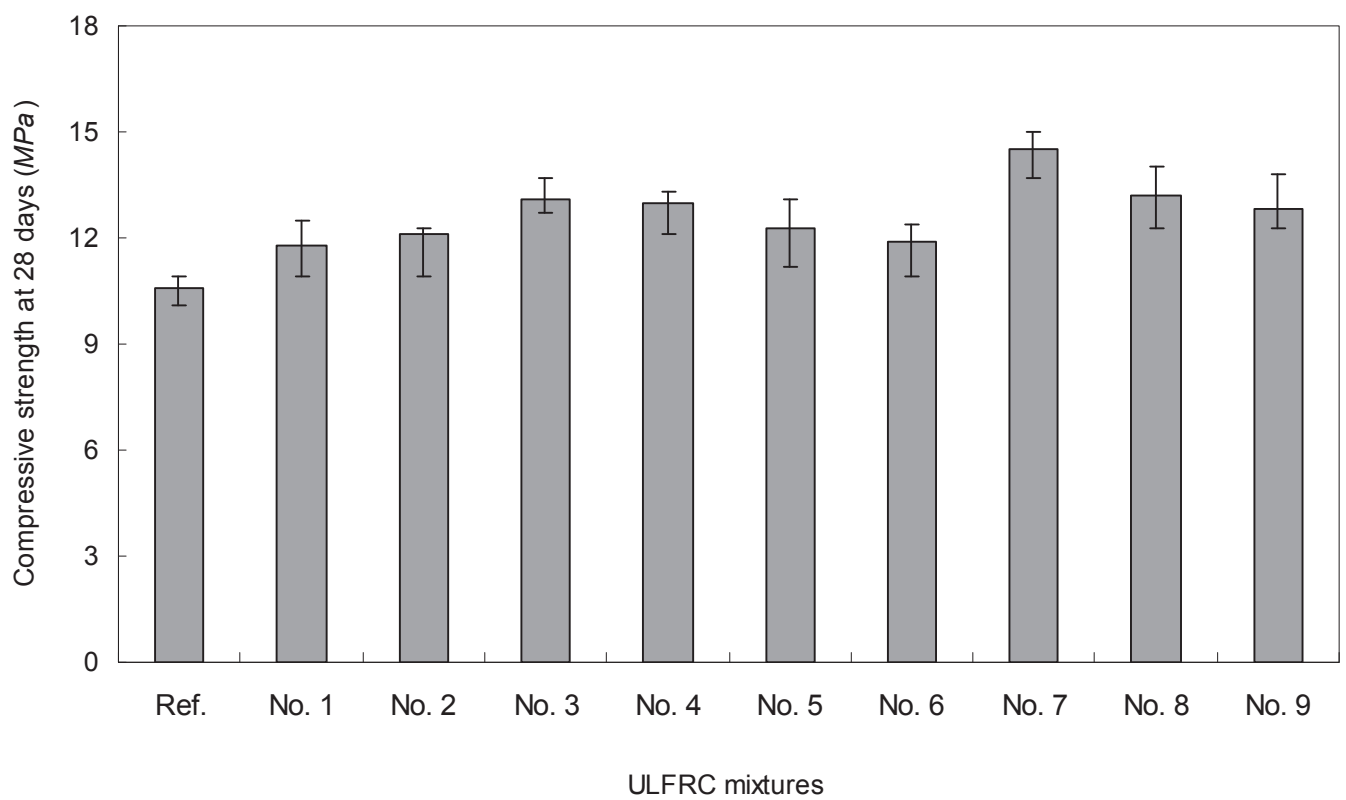

Fig. 7. Compressive strength (28 days) of the designed ULFRC. 
The results for mixtures No. 4-6 (with hybrid fibres) show that the compressive strength strongly depends on the proportion of long fibres (LPF) and short fibres (SPF). For instance, when the hybrid fibres are composed of $75 \%$ of LPF and $25 \%$ of SPF, the compressive strength of ULFRC is around $13.0 \mathrm{MPa}$, which is higher than that for the sample with only 0.2\% LPF (vol.) (12.1 MPa). Then, with an increasing SPF amount, the compressive strength slightly decreases to $11.9 \mathrm{MPa}$. This phenomenon should be attributed to the different reinforcing functions that LPF and SPF play in concrete. As already demonstrated by Markovic (2006), SPF can efficiently bridge micro-cracks, while the LPF is more efficient in resisting the development of macrocracks. Hence, when the micro-cracks are just generated in the concrete specimen, the SPF can effectively bridge them. As the micro-cracks grow and merge into larger macro-cracks, the LPF becomes increasingly active in the crack bridging. Hence, appropriate hybridization of LPF and SPF is beneficial for further improvement of the compressive strength of ULFRC.

To clarify the effect of relatively high fibre dosages (compared to the amount recommended by the fibre supplier), the compressive strengths of the concrete mixtures with $0.6 \%, 0.9 \%$ and $1.2 \%$ (vol.) of LPF are tested, as shown in Fig. 7 (mixtures No. 7-9). It is important to notice that the compressive strength of the mixture with $0.6 \%$ (vol.) of LPF is the highest among all the mixtures. However, with a further increase of LPF amount, the compressive strength of ULFRC slightly decreases, which is contrary to the results observed for mixtures No. 1-3. This should be attributed to the effect of LPF on the internal structure of ULFRC. As mentioned before, due to the fact that the utilized LWAs have very low densities (300-800 kg/ $\mathrm{m}^{3}$ ), it is relatively easy for the LPF to push apart the big particles and disturb the structure of the granular skeleton. When the LPF content is relatively high, more air voids will be entrapped into the ULFRC (as presented in Fig. 6), which is negative for the strength improvement of concrete. This can also be demonstrated by the density results shown in Fig. 5 and cross section of the ULFRC shown in Fig. 6. Although the addition of polypropylene fibres is beneficial for improving the compressive strength of ULFRC, the excessive LPF can significantly disturb the internal structure of concrete, which simultaneously decreases the density and compressive strength of ULFRC. Hence, it can be concluded that an appropriate LPF amount is crucial to produce ULFRC with an optimal compressive strength.

The relationship between the compressive strength and dry density for different types of LWC retrieved from the literature and for ULFRC developed here is shown in Fig. 8. A clear increase trend of the compressive strength can be observed when the dry densities of LWCs increase from about $400 \mathrm{~kg} / \mathrm{m}^{3}$ to around $2000 \mathrm{~kg} / \mathrm{m}^{3}$. Moreover, it is important to notice that the compressive strengths of ULFRC are higher than those of other LWCs (from the literature) with the same density, which implies that the developed ULFRC can bear higher loads without increasing its density range. This specific characteristic is very important to widen the application of ULFRC in practice. For instance, for the production of floating structures, the developed ULFRC can simultaneously fulfill the low density and load bearing requirements, which can effectively simplify the operation procedures and reduce the energy and labor demand. Hence, based on the method proposed in this study, it is possible to produce a LWC with a very low density and relatively good compressive strength simultaneously.

\subsubsection{Flexural behaviour}

Fig. 9 presents the 4-point bending test results of ULFRC with $0.1 \%, 0.2 \%$ and $0.3 \%$ (vol.) of LPF. It is clear that with an increase of displacement, the load firstly increases and then sharply decreases.
Then, the residual load of all the tested samples remains relatively stable with an increase of the displacement, which represents a slow fibre pull out process. Furthermore, it can also be found that the first crack load of the mixtures with $0.1 \%, 0.2 \%$ and $0.3 \%$ of LPF is $3.0,3.3$ and $3.6 \mathrm{kN}$, respectively. As can be found in the literature (Grünewald, 2004; Markovic, 2006), the load development of fibre reinforced concrete in bending test largely depends on the fibre type and amount. At the beginning of the 4-point bending test, the concrete matrix will endure the applied load. With an increase of the load, the used fibres will become more active and sustain part of the load. Afterwards, when the fibres and concrete matrix can not endure the applied load, the first crack will appear, and the endurable load will simultaneously reduce. After that, the fibres will be pulled out, and the development of the residual load will depend on the fibre type and amount. In this study, after the appearance of the first crack, the residual load of ULFRC (mixtures No. 1-3) remains relatively stable, which implies that to further improve the flexural properties of ULFRC, the utilized fibre amount should be appropriately increased.

The effect of hybrid polypropylene fibres on the flexural behaviour of ULFRC is illustrated in Fig. 10, which shows similar phenomenon as that presented in Fig. 9. Although the hybrid fibre can simultaneously restrict the development of micro and macrocracks, the relatively low fibre amount causes that the residual load (after the appearance of the first crack) can not be further enhanced. Consequently, combining the results shown in Figs. 9 and 10 , it can be concluded that to obtain a better post-crack response, more fibres should be appropriately added into the ULFRC mixture.

Fig. 11 shows the 4-point bending test results of ULFRC mixtures with relatively high fibre amount. It is noteworthy that these ULFRCs show substantially different post-crack response compared to the ULFRC mixtures with relatively low fibre amount (about $0.2 \%$ vol.). The load-displacement curves of the mixtures with $0.6 \%, 0.9 \%$ and $1.2 \%$ (vol.) of LPF can be mainly divided into three parts: elastic section, strain hardening section and strain softening section. After the first crack appears, their endurable loads firstly decrease and then gradually increase to a value (peak load) larger than the first crack load. In this study, the peak loads are enhanced with an increasing amount of the utilized LPF. However, it can also be found that the first crack load of the mixtures with $0.6 \%, 0.9 \%$ and $1.2 \%$ vol. of LPF reduces with an increase of the utilized LPF amount, which should be attributed to the influence of the high amount of fibres on the structure of the granular skeleton (in line with the effect of fibre amount on compressive strength), as discussed in the previous section.

In summary, based on the obtained results, it can be concluded that an optimized hybridization of fibres and an appropriate increase of the utilized LPF amount are beneficial for improving the mechanical properties of ULFRC. In practice, when the developed ULFRC is applied in elements with high toughness requirements, then a relatively high dosage of LFP should be added.

\subsection{Thermal conductivity}

The thermal conductivities of all the designed ULFRCs are illustrated in Fig. 12. It can be found that the thermal conductivity of ULFRC remains stable with the variation of fibre amount and hybridization, and all the tested thermal conductivities fluctuate around $0.165 \mathrm{~W} /(\mathrm{m} \mathrm{K})$. For instance, the highest thermal conductivity is about $0.171 \mathrm{~W} /(\mathrm{m} \mathrm{K})$ (No. 7), while the lowest one is around $0.160 \mathrm{~W} /(\mathrm{m} \mathrm{K})$ (No. 9). The small differences between the measurements are probably caused by internal or surface located air voids. Nevertheless, for the mixture No. 9, the effect of a higher number of long polypropylene fibres on the internal structure 


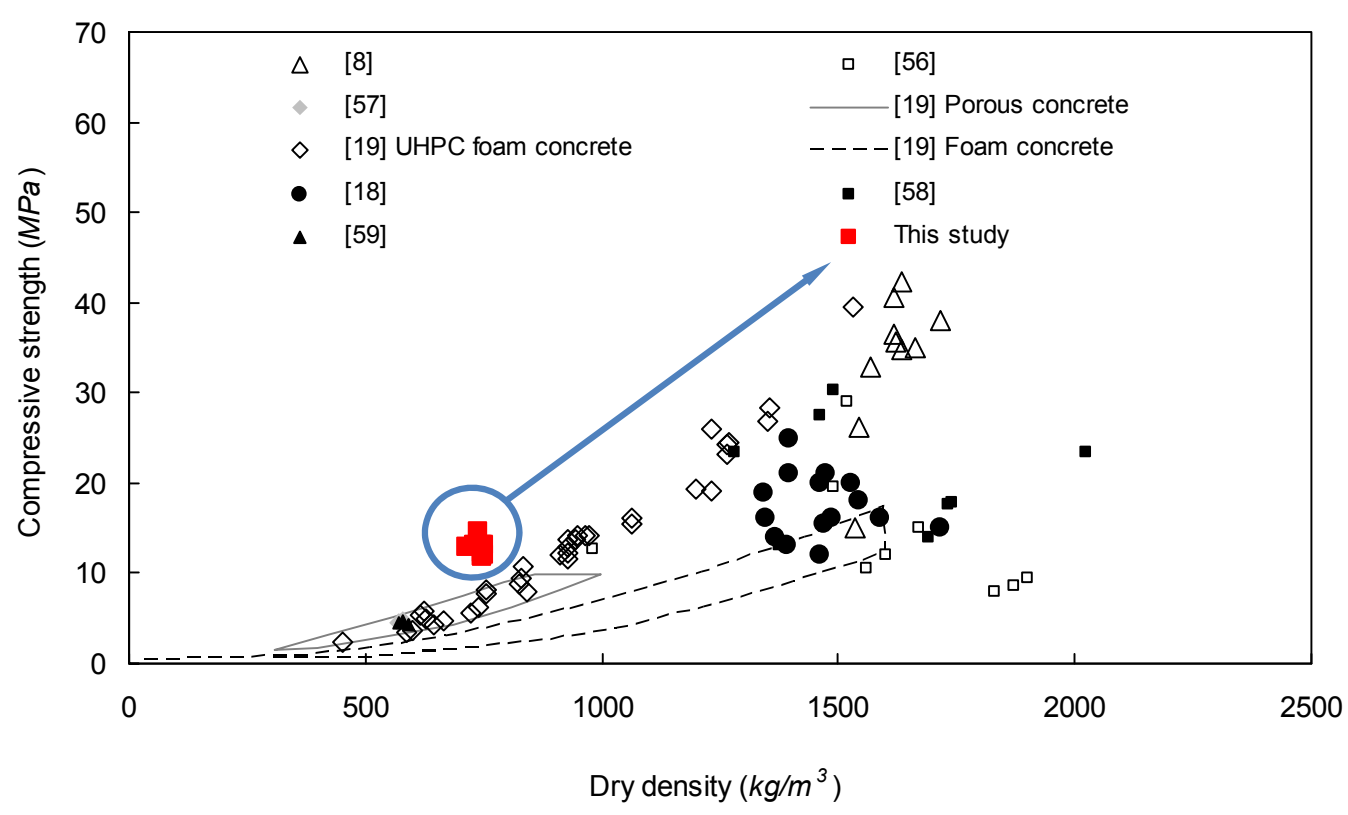

Fig. 8. Relationship between the compressive strength and dry density for different types of lightweight concrete.

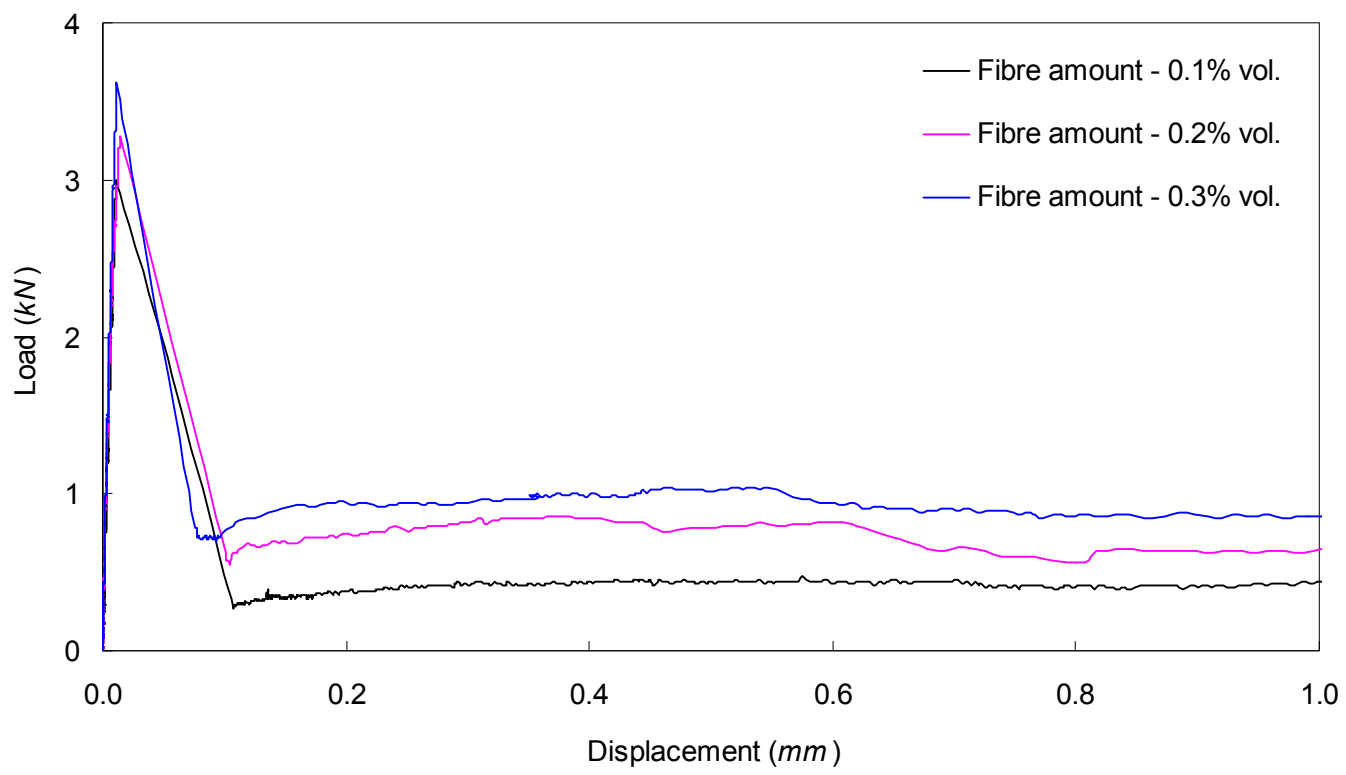

Fig. 9. 4-point bending test results of ULFRC with relatively low fibre amount $(0.1 \%, 0.2 \%$ and $0.3 \%$ vol.).

should also be a reason for the relatively low thermal conductivity. Normally, a dense granular structure results in better mechanical properties and a higher thermal conductivity. In this study, due to the fact that the relatively large amount of fibres can increase the entrapped air voids in ULFRC and reduce the ULFRC density, the thermal conductivity of ULFRC is simultaneously decreased.

The relationship between the compressive strength and thermal conductivity for different types of LWC retrieved from the literature and for ULFRC developed here are shown in Fig. 13. In general, it can be noticed that the thermal conductivity of LWC increases with an increase of its compressive strength. Due to the difference between the utilized raw materials and casting methods, the increasing trends of compressive strength along with the thermal conductivity varies for different types of LWCs. Moreover, it is important to find that the data points representing ULFRC are all above the points representing other LWCs, which means that the developed ULFRC has a higher compressive strength than the other LWCs with the same thermal conductivity range. Therefore, when the developed ULFRC is applied in the insulating elements, monolithic design concept can be utilized instead of multilayers design, which can significantly simplify the construction procedures and reduce the labor and energy cost.

In general, due to the low density, low thermal conductivity and acceptable mechanical properties, the developed ULFRC can be utilized as a new material for the production of floating structures, insulating elements or even load bearing elements. As the sustainable development is currently a crucial global issue and various industries are striving in saving energy and lowering the environmental impact, the developed ULFRC is a good candidate to be widely applied in the near future. 


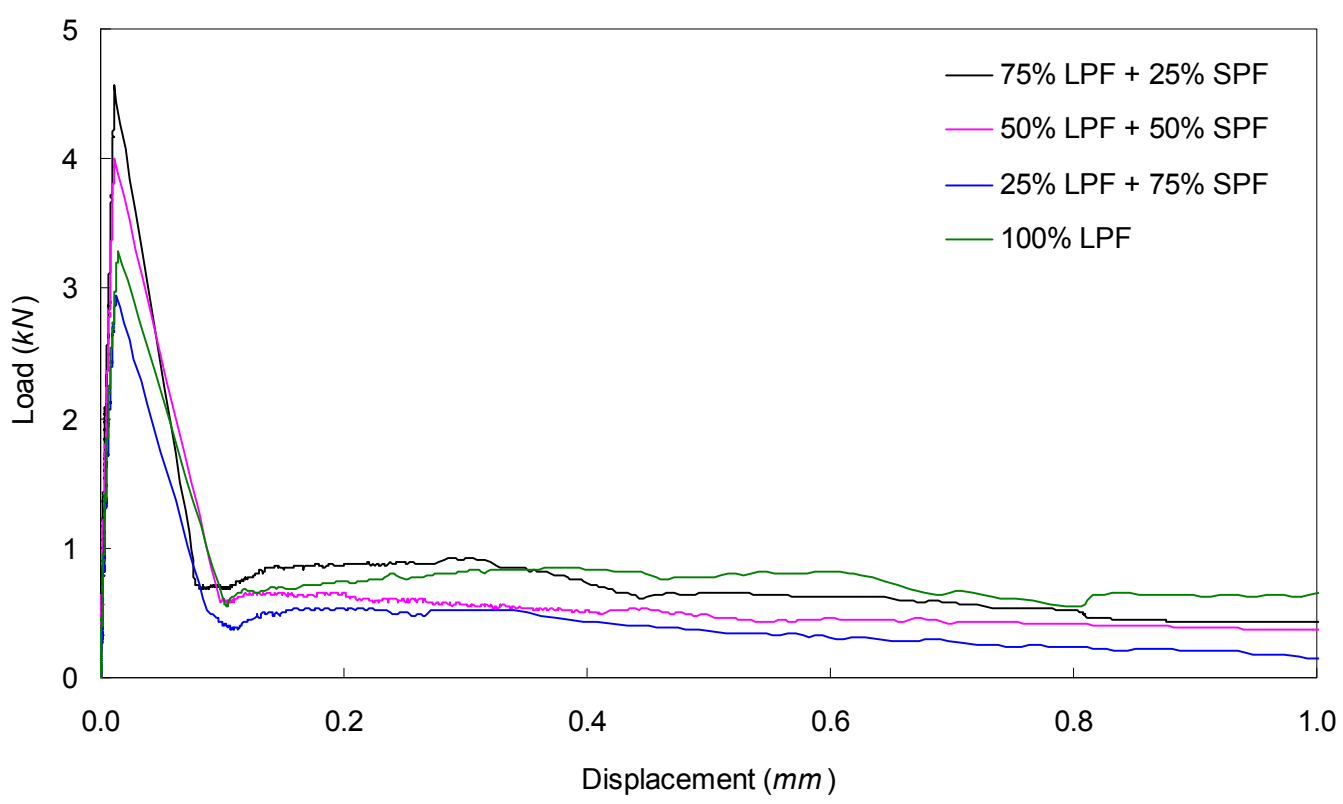

Fig. 10. 4-point bending test results of ULFRC with hybrid fibres (total fibre amount is fixed at $0.2 \%$ vol.).

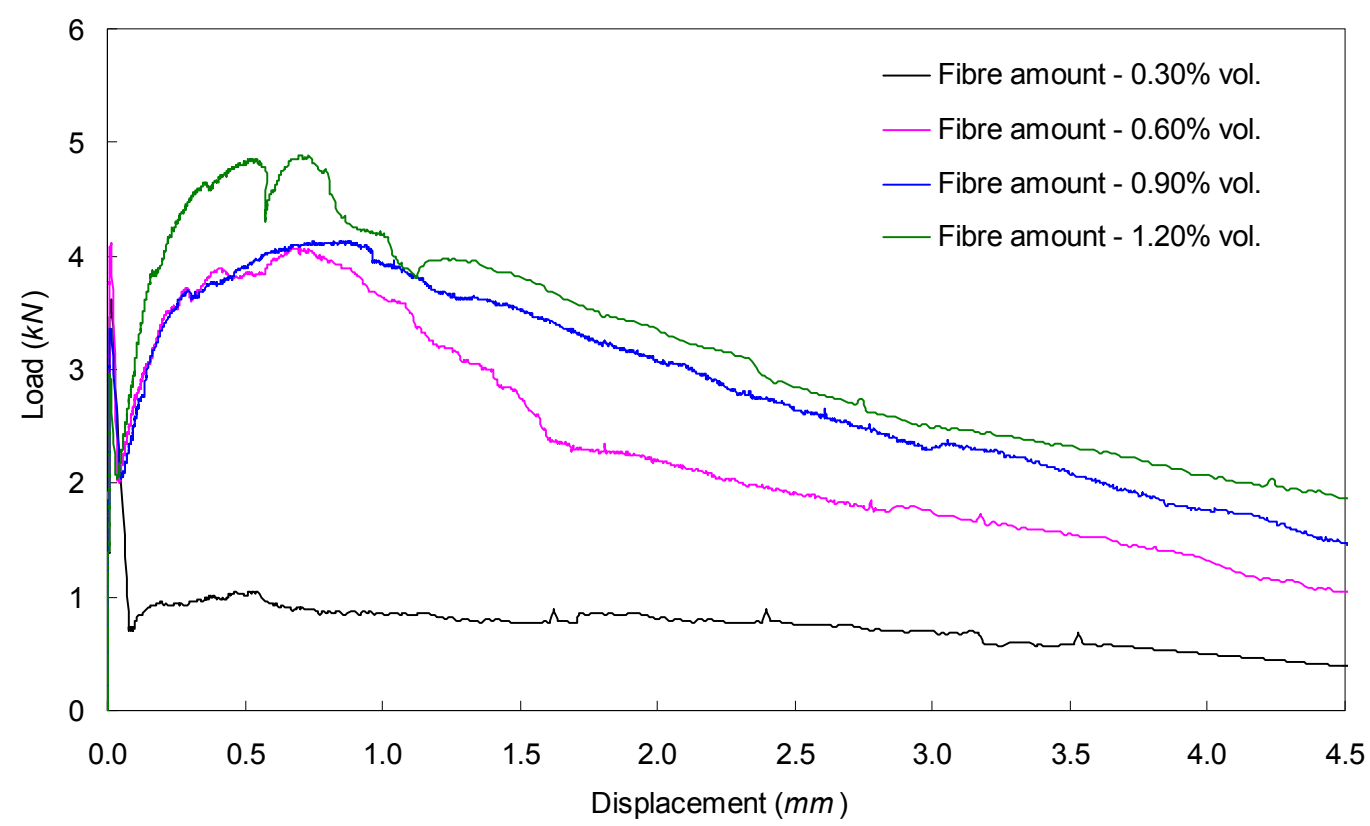

Fig. 11. 4-point bending test results of ULFRC with relatively high fibre content.

\section{Conclusions}

This paper addresses the development of Ultra-Lightweight Fibre Reinforced Concrete (ULFRC) applying expanded waste glass (lightweight aggregates). From the obtained results the following conclusions can be drawn:

- The dry density and thermal conductivity of the developed ULFRC are about $750 \mathrm{~kg} / \mathrm{m}^{3}$ and $0.165 \mathrm{~W} /(\mathrm{m} \mathrm{K})$, respectively. The used lightweight aggregates (LWA) homogeneously distribute in the concrete matrix. Compared to the other lightweight concretes (LWCs) with the same density or thermal conductivity, the developed ULFRC has significantly higher compressive strength (about $16 \mathrm{MPa}$ ).
- An optimized amount and hybridization of polypropylene fibres are crucial in improving the mechanical properties of ULFRC. To obtain a good post-crack response in the 4-point bending test, the added long polypropylene fibres (LPF) amount in the ULFRC mixture should be more than $0.6 \%$ (vol.) in this study, which can significantly improve the toughness of ULFRC. Hence, based on the different requirements from practice, the polypropylene fibre amount and type should be tailored.

- The relatively high LPF amount (about $1.2 \%$ vol.) can significantly influence the density and mechanical properties of ULFRC. Due to the fact that the utilized LWAs have very low density $\left(300-800 \mathrm{~kg} / \mathrm{m}^{3}\right)$, it is relatively easy for the LPF to push apart the big particles and disturb the structure of the granular 


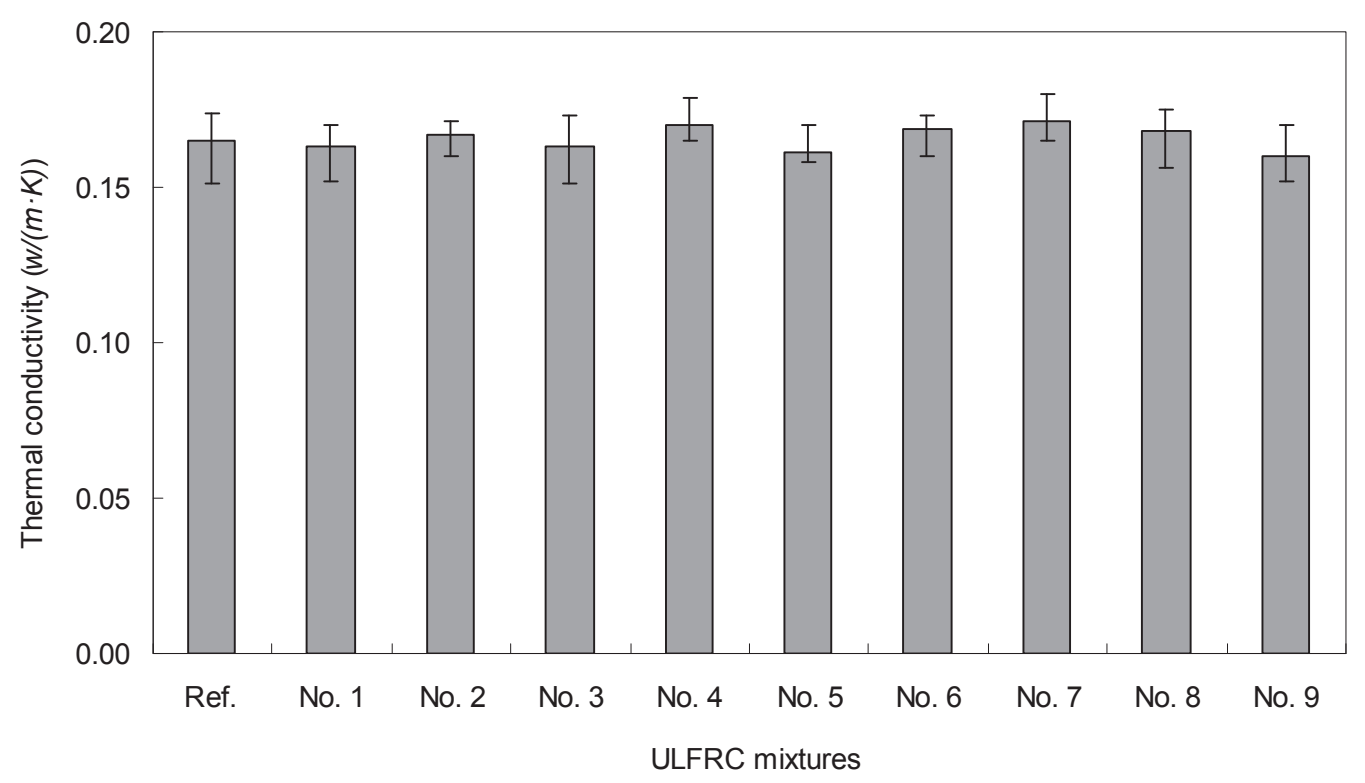

Fig. 12. Thermal conductivity of the designed ULFRC.

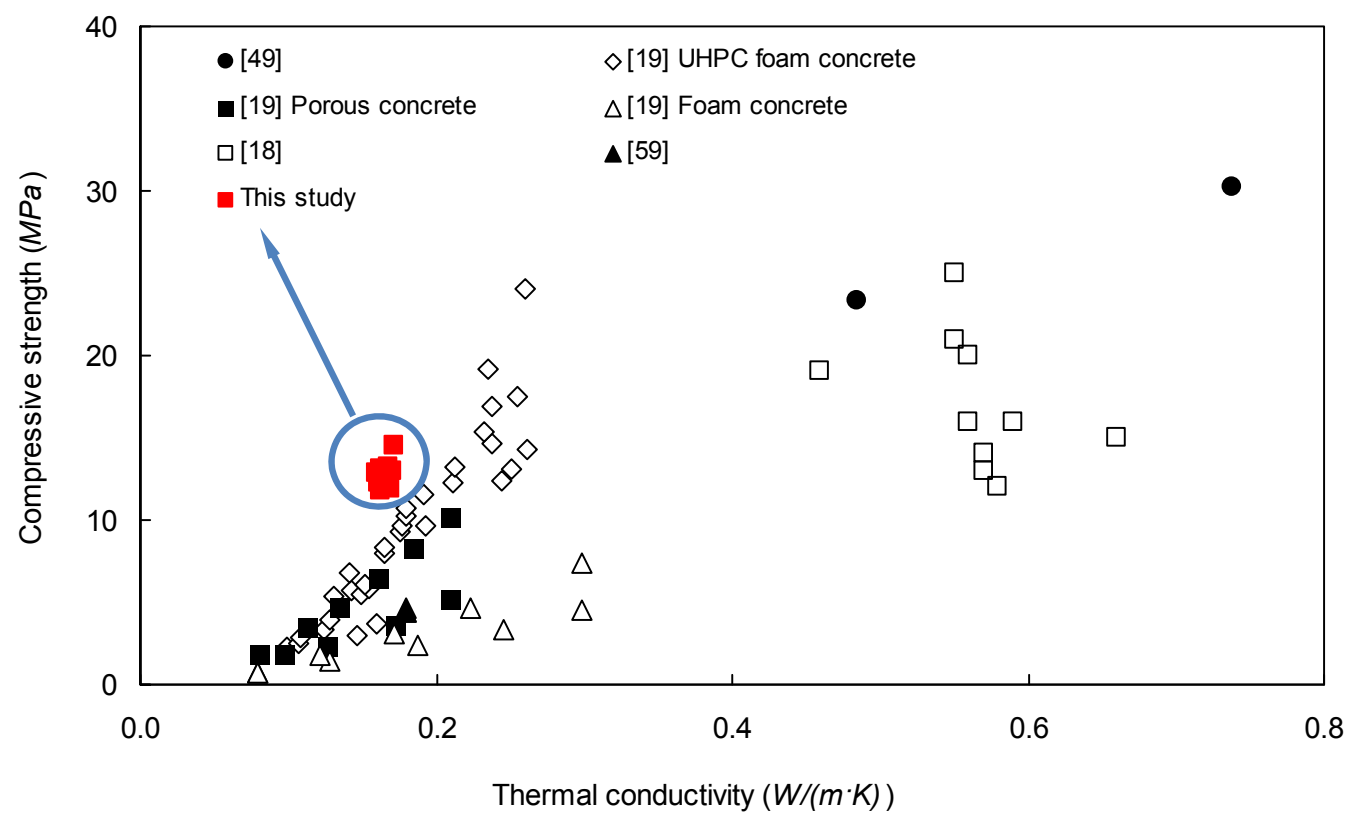

Fig. 13. Relationship between the compressive strength and the thermal conductivity for different types of lightweight concrete.

skeleton. Hence, when the additional LPF amount is relatively high, the density and mechanical properties of ULFRC can be simultaneously decreased.

- The low density, low thermal conductivity and acceptable mechanical properties of the developed ULFRC are beneficial for widening its application range in the practice. Since the available lands are prominently decreasing and there is a strong demand for the development of new building types, the developed ULFRC can be applied in the marine and floating constrictions. Moreover, due to the low thermal conductivity, it is also possible to utilize the ULFRC as a thermal insulating building material to design monolithic structures.

- The main raw material in ULFRC is the expanded glass aggregates, produced from expanded waste glass. Hence, the application of ULFRC provides a new method to efficiently reuse the waste glass, which is in line with the sustainable development.

\section{Acknowledgements}

The authors wish to express their gratitude to M.Sc. X. Gao for supporting the experimental work, and to the following sponsors of the Building Materials research group at TU Eindhoven: GranietImport Benelux, Kijlstra Betonmortel, Struyk Verwo, Attero, ENCI HeidelbergCement, Provincie Overijssel, Rijkswaterstaat Zee en Delta - District Noord, Van Gansewinkel Minerals, BTE, V.d. Bosch Beton, Selor, Twee "R" Recycling, GMB, Schenk Concrete Consultancy, Geochem Research, Icopal, BN International, Eltomation, 
Knauf Gips, Hess ACC Systems, Kronos, Joma, CRH Europe Sustainable Concrete Centre, Cement\&BetonCentrum, Heros and Inashco (in chronological order of joining).

\section{List of symbols and abbreviations}

$\begin{array}{ll}\text { Symbols } & \\ \mathrm{D} & \text { Particle size }(\mu \mathrm{m}) \\ \mathrm{D}_{\max } & \text { Maximum particle size }(\mu \mathrm{m}) \\ \mathrm{D}_{\min } & \text { Minimum particle size }(\mu \mathrm{m}) \\ \mathrm{P}_{\operatorname{mix}} & \text { Composed mix }(-) \\ \mathrm{P}_{\operatorname{tar}} & \text { Target curve }(-) \\ \mathrm{P}(\mathrm{D}) & \text { Fraction of the total solids being smaller than size } \mathrm{D}(-) \\ \mathrm{q} & \text { Distribution modulus }(-) \\ \mathrm{RSS} & \text { Sum of the squares of the residuals }(-)\end{array}$

\section{Abbreviations \\ CPM Compressive Packing Model \\ LPDM Linear Packing Density Model \\ LPF Long polypropylene fibres \\ LWA Lightweight Aggregate \\ LWC Lightweight Concrete \\ OPC Ordinary Portland Cement \\ SPF Short polypropylene fibres \\ ULFRC Ultra-Lightweight Fibre Reinforced Concrete}

\section{References}

Andreasen, A.H.M., Andersen, J., 1930. Über die Beziehungen zwischen Kornabstufungen und Zwischenraum in Produkten aus losen Körnern (mit einigen Experimenten). Kolloid-Zeitschrift 50, 217-228 (In German).

Bravo, M., Brito, J., Pontes, J., Evangelista, L., 2015. Mechanical performance of concrete made with aggregates from construction and demolition waste recycling plants. J. Clean. Prod. 99, 59-74.

Brouwers, H.J.H., Radix, H.J., 2005. Self compacting concrete: theoretical and experimental study. Cem. Concr. Res. 35, 2116-2136.

BS EN 12390-2, 2000. Testing Hardened Concrete - Part 2: Making and Curing Specimens for Strength Test. British Standards Institution-BSI and CEN European Committee for Standardization.

BS EN 12390-3, 2009. Testing Hardened Concrete Part 3: Compressive Strength of Test Specimens. British Standards Institution-BSI and CEN European Committee for Standardization.

BS EN 12390-5, 2009. Testing Hardened Concrete - Part 5: Flexural Strength of Test Specimens. British Standards Institution-BSI and CEN European Committee for Standardization.

BS EN 12390-7, 2009. Testing Hardened Concrete - Part 7: Density of Hardened Concrete. British Standards Institution-BSI and CEN European Committee for Standardization.

BS EN 12350-5, 2009. Testing Fresh Concrete - Part 5: Flow Table Test. British Standards Institution-BSI and CEN European Committee for Standardization.

BS EN 206-1, 2001. Concrete - Part 1: Speciation, Performance, Production and Conformity.

Castro, S., Brito, J., 2013. Evaluation of the durability of concrete made with crushed glass aggregates. J. Clean. Prod. 41, 7-14.

Chandra, S., Berntsson, L., 2003. Lightweight Aggregate Concrete Science, Technology and Applications. Standard Publishers Distributors, Delhi, India, ISBN 81-8014-052-0.

Choi, J., Zi, G., Hino, S., Yamaguchi, K., Kim, S., 2014. Influence of fiber reinforcement on strength and toughness of all-lightweight concrete. Constr. Build. Mater 63, 132-141.

De Larrard, F., Sedran, T., 1994. Optimization of ultra-high-performance concrete by the use of a packing model. Cem. Concr. Res. 1994 (24), 997-1009.

De Larrard, F., Sedran, T., 2002. Mixture-proportioning of high-performance concrete. Cem. Concr. Res. 2002 (32), 1699-1704.

Fennis, S.A.A.M., Walraven, J.C., den Uijl, J.A., 2009. The use of particle packing models to design ecological concrete. Heron 54, 185-204.

Funk, J.E., Dinger, D.R., 1994. Predictive Process Control of Crowded Particulate Suspensions, Applied to Ceramic Manufacturing. Kluwer Academic Publishers, Boston, the United States.
Guo, Y., Zhang, J., Chen, G., Xie, Z., 2014. Compressive behaviour of concrete structures incorporating recycled concrete aggregates, rubber crumb and reinforced with steel fibre, subjected to elevated temperatures. J. Clean. Prod. 72 (1), 193-203.

Grünewald, S., 2004. Performance-based Design of Self-compacting Fibre Reinforced Concrete. Delft University of Technology, Delft, the Netherlands.

Hunger, M., 2010. An Integral Design Concept for Ecological Self-compacting Concrete. PhD thesis. Eindhoven University of Technology, Eindhoven, the Netherlands.

Hüsken, G., Brouwers, H.J.H., 2008. A new mix design concept for earth-moist concrete: a theoretical and experimental study. Cem. Concr. Res. 38, 1246-1259.

Kayali, O., Haque, M.N., Zhu, B., 2003. Some characteristics of high strength fiber reinforced lightweight aggregate concrete. Cem. Concr. Comp. 25 (2), 207-213.

Kidalova, L., Stevulova, N., Terpakova, E., Sicakova, A., 2012. Utilization of alternative materials in lightweight composites. J. Clean. Prod. 34, 116-119.

Libre, N.A., Shekarchi, M., Mahoutian, M., Soroushian, P., 2011. Mechanical properties of hybrid fiber reinforced lightweight aggregate concrete made with natural pumice. Constr. Build. Mater 25 (5), 2458-2464.

Ling, T.C., Poon, C.S., 2012. Feasible use of recycled CRT funnel glass as heavyweight fine aggregate in barite concrete. J. Clean. Prod. 33, 42-49.

Ling, T.C., Poon, C.S., 2014. Use of recycled CRT funnel glass as fine aggregate in drymixed concrete paving blocks. J. Clean. Prod. 68, 209-214.

Markovic, I., 2006. High-performance Hybrid-fibre Concrete - Development and Utilisation. Technische Universität Delft. Ph.D. thesis.

Mazaheripour, H., Ghanbarpour, S., Mirmoradi, S.H., Hosseinpour, I., 2011. The effect of polypropylene fibers on the properties of fresh and hardened lightweight self-compacting concrete. Constr. Build. Mater 25 (1), 351-358.

Neville, A.M., 2011. Properties of Concrete, fifth ed.

Pelisser, F., Barcelos, A., Santos, D., Peterson, M., Bernardin, A.M., 2012. Lightweight concrete production with low Portland cement consumption. J. Clean. Prod. 23 (1), 68-74.

Quercia, G., Spiesz, P., Hüsken, G., Brouwers, H.J.H., 2014. SCC modification by use of amorphous nano-silica. Cem. Concr. Comp. 45, 69-81.

Rashad, A.M., 2014. Recycled waste glass as fine aggregate replacement in cementitious materials based on Portland cement. Constr. Build. Mater 72, 340-357.

Shafigh, P., Mahmud, H.B., Jumaat, M.Z.B., Ahmmad, R., Bahri, S., 2014. Structural lightweight aggregate concrete using two types of waste from the palm oil industry as aggregate. J. Clean. Prod. 80, 187-196.

Schauerte, M., Trettin, R., 2012. Neue Schaumbetone mit gesteigerten mechanischen ind physikalischen Eigenschaften. In: Proceedings of the 18th Ibausil, International Conference on Building Materials. Bauhaus-Universitat Weimar, Weimar, Germany.

Topçu, I.B., Uygunoglu, T., 2010. Effect of aggregate type on properties of hardened selfconsolidating lightweight concrete (SCLC). Constr. Build. Mater 24, 1286-1295.

Yang, K.H., Song, J.K., Song, K.I., 2013. Assessment of $\mathrm{CO}_{2}$ reduction of alkaliactivated concrete. J. Clean. Prod. 39, 265-272.

Yang, K.H., Lee, K.H., Song, J.K., Gong, M.H., 2014. Properties and sustainability of alkali-activated slag foamed concrete. J. Clean. Prod. 68, 226-233.

Yu, Q., Spiesz, P.R., Brouwers, H.J.H., 2013. Ultra-lichtbeton voor monoliete gevelconstructies: combinatie tussen mechanische en thermische eigenschappen. Cement 65, 7.

Yu, Q.L., Spiesz, P., Brouwers, H.J.H., 2014a. Design of ultra-lightweight concrete: towards monolithic concrete structure. Vestn. MGSU 4, 98-106.

Yu, Q.L., Spiesz, P., Brouwers, H.J.H., 2015a. Ultra-lightweight concrete: conceptual design and performance evaluation. Cem. Concr. Comp. 61, 18-28.

Yu, R., Shui, Z.H., 2013. Influence of agglomeration of a recycled cement additive on the hydration and microstructure development of cement based materials. Constr. Build. Mater. 49, 841-851.

Yu, R., Shui, Z.H., 2014. Efficient reuse of the recycled construction waste cementitious materials. J. Clean. Prod. 78, 202-207.

Yu, R., Spiesz, P., Brouwers, H.J.H., 2014c. Mix design and properties assessment of Ultra-High Performance Fibre Reinforced Concrete (UHPFRC). Cem. Concr. Res. 2014 (56), 29-39.

Yu, R., Tang, P., Spiesz, P., Brouwers, H.J.H., 2014d. A study of multiple effects of nano-silica and hybrid fibres on the properties of Ultra-High Performance Fibre Reinforced Concrete (UHPFRC) incorporating waste bottom ash (WBA). Constr. Build. Mater. 60, 98-110.

Yu, R., Spiesz, P., Brouwers, H.J.H., 2014e. Effect of nano-silica on the hydration and microstructure development of Ultra-High Performance Concrete (UHPC) with a low binder amount. Constr. Build. Mater. 65, 140-150.

Yu, R., Spiesz, P., Brouwers, H.J.H., 2015b. Development of an eco-friendly Ultra-High Performance Concrete (UHPC) with efficient cement and mineral admixtures uses. Cem. Concr. Comp. 55, 383-394. 